\title{
Profil dermatofitosis di Poliklinik Kulit dan Kelamin RSUP Prof. Dr. R. D. Kandou Manado periode Januari - Desember 2013
}

\author{
${ }^{1}$ Cyndi E. E. J. Sondakh \\ ${ }^{2}$ Thigita A. Pandaleke \\ ${ }^{2}$ Ferra O. Mawu
}

\author{
${ }^{1}$ Kandidat Skripsi Fakultas Kedokteran Universitas Sam Ratulangi Manado \\ ${ }^{2}$ Bagian/SMF Kulit dan Kelamin RSUP Prof. Dr. R. D. Kandou Manado \\ Email: cyndisondakh_12065@yahoo.com
}

\begin{abstract}
Dermatophytosis is a disorder of tissues with keratinized ephithelia e. g. stratum corneum of epidermis, hair, and nails, caused by dermatophyte fungi from arthrodermataceae family. This family has more than 40 species divided into three genera: Epidermophyton, Microsporum, and Trichophyton. The distribution of dermatophytosis is based on its location: tinea capitis, tinea barbae, tinea cruris, tinea pedis et manum, tinea unguium, and tinea corporis. This study aimed to obtain the profile of dermatophytosis classified by location, age, gender, job and therapy at the Dermatovenerology Clinic of Prof. Dr. R. D. Kandou Hospital Manado during the period of January-December 2013. The results showed that of 4,099 skin disease cases in 2013, there were $153(3.7 \%)$ cases of dermatophytosis with the most frequent found was tinea cruris (35.3\%), the age group was 45-64 years old (32.7\%), most patients were female (60.8\%), commonly housewife (22.9\%), and the most treatmen tused was topical therapy (68.6\%).
\end{abstract}

Keywords: dermatophyte, dermatophytosis, tinea

\begin{abstract}
Abstrak: Dermatofitosis merupakan penyakit pada jaringan yang mengandung zat tanduk, seperti stratum korneum pada epidermis, rambut dan kuku, yang disebabkan oleh jamur dermatofita dari famili arthrodermataceae. Famili ini terdiri lebih dari 40 spesies yang dibagi dalam tiga genus: Epidermophyton, Microsporum, dan Trichophyton. Pembagian dermatofitosis berdasarkan lokasinya yaitu tinea kapitis, tinea barbae, tinea kruris, tinea pedis et manum, tinea unguinum, dan tinea korporis. Penelitian ini bertujuan untuk mengetahui profil dermatofitosis di Poliklinik Kulit dan Kelamin RSUP Prof. Dr. R. D. Kandou Manado periode Januari-Desember 2013 berdasarkan klasifikasi lokasi, usia, jenis kelamin, pekerjaan dan terapi yang diberikan. Hasil penelitian menunjukkan bahwa dari total 4.099 kasus penyakit kulit di tahun 2013, terdapat $153(3,7 \%)$ kasus dermatofitosis dengan persentase tertingggi yang diperoleh ialah: tinea kruris $(35,3 \%)$, golongan umur $45-64$ tahun $(32,7 \%)$, jenis kelamin perempuan $(60,8 \%)$, ibu rumah tangga (22.9\%), dan terapi kombinasi (68.6\%)
\end{abstract}

Kata kunci: dermatofitosis, tinea

Masalah kesehatan masih menjadi perhatian utama di masyarakat. Perkembangan ilmu dan teknologi yang ada saat ini banyak memberi kontribusi dalam bidang kesehatan, namun hal itu tidak mengurangi minat serta perhatian masyarakat terhadap masalah kesehatan.
Pemeliharaan kesehatan dapat dimulai dari memperhatikan kesehatan organ tubuh. Kulit merupakan organ yang terletak di sisi terluar tubuh manusia dan menjadi organ yang mendapat pengamatan secara terus menerus baik oleh diri sendiri maupun orang lain. Dalam kondisi sehat, kulit dapat 
menjadi sumber percaya diri dan saat sakit dapat menimbulkan keresahan. ${ }^{1}$

Di Indonesia yang menjadi penyebab penyakit kulit biasanya akibat infeksi bakteri, jamur, virus, parasit yang dapat dipengaruhi oleh beberapa hal sehinnga sering memberikan perbedaan gambaran klinis penyakit kulit seperti faktor iklim, kebiasaan dan lingkungan. ${ }^{2}$

Dermatofitosis merupakan penyakit pada jaringan yang mengandung zat tanduk, misalnya stratum korneum pada epidermis, rambut dan kuku, yang disebabkan oleh jamur dermatofita dari famili arthrodermataceae dengan lebih dari 40 spesies yang dibagi dalam tiga genus : Epidermophyton, Microsporum, dan Trichophyton. ${ }^{1,3}$ Kemampuannya untuk membentuk ikatan molekuler terhadap keratin dan menggunakannya sebagai sumber makanan menyebabkan mereka mampu berkolonisasi pada jaringan keratin. $^{4}$ Pada penamaan infeksi klinis dermatofitosis, kata tinea mendahului nama latin untuk bagian tubuh yang terkena. ${ }^{5}$

Tinea kapitis merupakan infeksi jamur menular pada kepala yang menyarang batang rambut ${ }^{3}$ dan merupakan penyebab kerontokan rambut yang sering dijumpai pada anak-anak. Secara klinis dapat ditemukan bercak bundar berwarna merah, bersisik dan kadang menjadi gambaran klinis yang lebih berat disebut kerion. ${ }^{6}$

Tinea barbae hanya terjadi pada pria. Umumnya menimbulkan lesi yang khas unilateral dan lebih sering melibatkan area janggut daripada kulit atau bibir bagian atas. $^{3}$

Tinea kruris merupakan dermatofitosis yang sering ditemukan pada daerah lipat paha, genitalia, daerah pubis, perineum dan perianal. Kelainan ini dapat bersifat akut atau kronis, bahkan dapat berlangsung seumur hidup. ${ }^{1,7}$ Penamaan penyakit ini merupakan istilah yang tidak cocok, karena dalam bahasa Latin "kruris" berarti kaki. Penyakit ini merupakan penyakit terbanyak yang ditemukan di daerah inguinal, yaitu sekitar $65-80 \%$ dari semua penyakit kulit di inguinal, sehingga beberapa kepustakaan menyatakan inguinal intertrigo sebagai sinonim dari tinea kruris. ${ }^{4}$

Tinea pedis merupakan infeksi jamur pada kaki. Sering dijumpai pada orang yang dalam kesehariannya banyak bersepatu tertutup disertai perawatan kaki yang buruk dan para pekerja dengan kaki yang selalu atau sering basah ${ }^{1}$. Tinea pedis biasanya menyerang sela-sela kaki dan telapak kaki. Tinea pedis atau ringworm of the foot adalah infeksi dermatofita pada kaki, terutama pada sela jari dan telapak kaki. Tinea pedis merupakan infeksi jamur yang sering terjadi. ${ }^{8}$ Penyebab paling sering ditemukan yaitu Trichophyton rubrum yang dapat mengakibatkan kelainan menahun. Infeksi jamur dermatofita yang menyerang kulit telapak tangan, punggung tangan dan jari tangan disebut tinea manum. ${ }^{1,3}$

Tinea unguium disebut juga dermatophytic onychomycosis, ringworm of the nail $)^{1,7}$ adalah kelainan pada kuku yang disebabkan infeksi jamur dermatofita. Penyebab tersering tinea unguium yaitu $T$. mentagrophytes dan T. rubrum. ${ }^{1}$

Tinea imbrikata merupakan dermatofitosis dengan gambaran khas berupa kulit bersisik dengan sisik yang melingkarlingkar dan terasa gatal. Tinea imbrikata disebabkan oleh T.concentricum. Penyakit ini dapat ditemukan di berbagai wilayah Indonesia seperti Kalimantan, Sulawesi, Papua, Kepulauan Aru dan Kei, dan Sulawesi Tengah. Penyakit ini dapat menyerang seluruh permukaan kulit halus, sehingga sering digolongan dalam tinea korporis. Lesi bermula sebagai makula eritematosa yang gatal, kemudian timbul skuama yang agak tebal dan terletak konsentris dengan susunan seperti genting. Lesi makin lama makin melebar tanpa meninggalkan penyembuhan di bagian tengah. Pruritus yang hebat dan dapat terjadi likenifikasi. Lesi kadang hipopigmentasi. $^{9}$

Tinea inkognito merupakan infeksi dermatofita yang mengalami modifikasi sehingga tidak tampak bentuk klinis yang khas oleh karena telah diobati dengan kortikosteroid topikal kuat. Tinea fasialis dan tinea aksilaris penamaan yang 
menunjuk ke daerah kelainan dan merupakan varian tinea korporis. Tinea sirsinata, arkuata juga merupakan penamaan deskriptif morfologis.

Infeksi penyakit oleh jamur dapat ditemukan hampir di seluruh daerah Indonesia karena merupakan wilayah yang baik untuk pertumbuhan jamur. ${ }^{10}$ Iklim dan kondisi geogafis di Indonesia memudahkan pertumbuhan jamur sehingga menyebabkan banyaknya kasus infeksi jamur. ${ }^{11}$

Insidensi penyakit yang disebabkan oleh jamur di Indonesia berkisar 2,93-27,6\% untuk tahun 2009-2011. ${ }^{6}$ Di Manado sendiri menurut penelitian oleh Bertus ${ }^{11}$ di RSUP Prof. Dr. R. D. Kandou periode Januari - Desember 2012 didapatkan 65 kasus (1,61\%) dermatofitosis dengan persentasi kasus terbanyak yaitu tinea kruris sebanyak 36 kasus (55,38\%) dari keseluruhan kasus dermatofitosis.

Penelitian ini bertujuan untuk mengetahui profil dermatofitosis di Poliklinik Kulit dan Kelamin RSUP Prof. Dr. R. D. Kandou Manado periode JanuariDesember 2013 berdasarkan klasifikasi lokasi, usia, jenis kelamin, pekerjaan dan terapi yang diberikan

\section{METODE PENELITIAN}

Jenis penelitian ini ialah deskriptif retrospektif dengan sarana data rekam medik pasien dermatofitosis yang tercatat di Instalasi Rekam Medik serta Poliklinik Kulit dan Kelamin RSUP Prof. Dr. R. D. Kandou periode Januari - Desember 2013. Sampel penelitian diambil dari semua kasus baru yang tercatat menderita dermatofitosis. Variabel penelitian yaitu klasifikasi berdasarkan lokasi, umur, jenis kelamin, pekerjaan, dan terapiyang digunakan.

\section{HASIL PENELITIAN}

Distribusi jumlah kasus dermatofitosis tahun 2013 di RSUP Prof. Dr. R. D. Kandou Manado yaitu 153 (3.7\%) kasus dari 4099 (100\%) total kasus penyakit kulit (Tabel 1).

Distribusi kasus dermatofitosis di RSUP Prof. Dr. R. D. Kandou Manado Tahun 2013 yang diklasifikasikan berdasarkan lokasinya diadapatkan 54 kasus (35.3\%) tinea kruris, kemudian tinea korporis dengan 50 kasus (32,7\%), tinea kapitis 11 kasus (7,2\%), lalu tinea unguium atau onikomikosis dengan 8 kasus $(5,3 \%)$ dan tinea pedis et manum 4 kasus (2,6\%). Selain itu ada juga lokasi kombinasi tinea korporis et kruris dan tinea kruris et korporis dengan 26 kasus (17,0\%). Untuk kasus dermatofitosis tahun 2013 tidak ditemukan data mengenai tinea barbae dan tinea imbrikata (Tabel 2).

Tabel 1. Distribusi Kasus Dermatofitosis Berdasarkan Jumlah Kasus

\begin{tabular}{cccc}
\hline Tahun & $\begin{array}{c}\text { Jumlah } \\
\text { Seluruh } \\
\text { Kasus }\end{array}$ & $\begin{array}{c}\text { Jumlah Kasus } \\
\text { Dermatofitosis }\end{array}$ & (\%) \\
\hline 2013 & 4099 & 153 & 3.7 \\
\hline
\end{tabular}

Tabel 2. Distribusi Kasus Dermatofitosis Berdasarkan Klasifikasi Lokasi

\begin{tabular}{ccc}
\hline Klasifikasi & Jumlah & $\mathbf{( \% )}$ \\
Dermatofitosis & Kasus & \\
\hline Tinea Kapitis & 11 & 7.2 \\
Tinea Barbae & - & 0 \\
Tinea Korporis & 50 & 32.7 \\
Tinea Kruris & 54 & 35.3 \\
Lokasi Kombinasi & 26 & 17.0 \\
Tinea Pedis et & 4 & 2.6 \\
Manum & & \\
Tinea Unguium & 8 & 5.2 \\
Tinea Imbrikata & - & 0 \\
Total & 153 & 100.0 \\
\hline
\end{tabular}

Distribusi kasus dermatofitosis berdasarkan umur pasien saat memeriksakan diri diRSUP Prof. Dr. R. D. Kandou Manado Tahun 2013 dari total 153 kasus dermatofitosis yaitu jumlah terbanyak pada golongan umur 45-64 tahun dengan 50 kasus (32,7\%), diikuti pasien dengan umur 25-44 tahun dengan 41 kasus (26.8\%), kemudian $\geq 65$ tahun 23 kasus (15,0\%), untuk golongan umur 15-24 tahun dan 5-14 tahun dengan selisih 1 kasus, masing-masing 17 kasus $(11,1 \%)$ dan 16 kasus (10,5\%), untuk golongan umur 1-5 tahun terdapat 6 kasus (3,9\%), sedangkan golongan umur $<1$ tahun tidak terdapat 
Sondakh, Pandaleke, Mawu: Profil dermatofitosis di...

kasus untuk tahun 2013 (Tabel 3).

Tabel 3. Distribusi Kasus Dermatofitosis Berdasarkan Klasifikasi Umur (WHO)

\begin{tabular}{ccc}
\hline Umur (tahun) & $\begin{array}{c}\text { Jumlah } \\
\text { Kasus }\end{array}$ & $\mathbf{( \% )}$ \\
\hline$<1$ tahun & - & 0 \\
$1-4$ tahun & 6 & 3,9 \\
$5-14$ tahun & 16 & 10,5 \\
$15-24$ tahun & 17 & 11,1 \\
$25-44$ tahun & 41 & 26,8 \\
$45-64$ tahun & 50 & 32,7 \\
$\geq 65$ tahun & 23 & 15,0 \\
Total & 153 & 100,0 \\
\hline
\end{tabular}

Distribusi kasus dermatofitosis berdasarkan jenis kelamin diRSUP Prof. Dr. R. D. Kandou Manado Tahun 2013 dari total 153 kasus dermatofitosis yaitu lakilaki sebanyak 60 orang $(39,2 \%)$ dan terbanyak yaitu pasien perempuan dengan 93 orang $(60,8 \%)$ (Tabel 4$)$.

Tabel 4. Distribusi Kasus Dermatofitosis Berdasarkan Jenis Kelamin Pasien

\begin{tabular}{ccc}
\hline Jenis Kelamin & Jumlah Kasus & $(\%)$ \\
\hline Laki-laki & 60 & 39.2 \\
Perempuan & 93 & 60.8 \\
Total & 153 & 100.0 \\
\hline
\end{tabular}

Distribusi kasus dermatofitosis berdasarkan pekerjaan ditemukan pasien ibu rumah tangga sebagai kasusterbanyak dengan 35 (22,9\%) orang, siswa 28 kasus (18\%) dan pensiunan sebanyak 26 kasus (16,9\%), kemudian pegawai dengan 21 kasus $(13,7 \%)$ yang terdiri dari Pegawai Negri Sipil (PNS), pegawai swasta termasuk juga dosen dan pendeta. Wiraswasta 14 kasus (9,2\%), mahasiswa dengan 7 kasus (4.6\%), dan petani, tukang dan yang belum bekerja (belum bekerja dan belum sekolah karena masih dibawah umur) masing-masing 1 kasus (0,7\%), 3 kasus (1,9\%) dan 4 kasus (2,6\%).

Dari keseluruhan kasus dermatofitosis sebanyak 153 kasus terdapat 14 kasus (9.2\%) data yang tidak diketahui atau tidak tercatat (Tabel 5).
Tabel 5. Distribusi Kasus Dermatofitosis Berdasarkan Pekerjaan Pasien

\begin{tabular}{ccc}
\hline Pekerjaan & $\begin{array}{c}\text { Jumlah } \\
\text { Kasus }\end{array}$ & (\%) \\
\hline Pensiunan & 26 & 16,9 \\
Pegawai & 21 & 13,7 \\
Wiraswasta & 14 & 9,2 \\
Ibu Rumah Tangga & 35 & 22,9 \\
Petani & 1 & 0,7 \\
Tukang/Pekerja & 3 & 1,9 \\
bangunan & & \\
Mahasiswa & 7 & 4,6 \\
Siswa & 28 & 18,3 \\
Belum bekerja & 4 & 2,6 \\
(tidak diketahui) & 14 & 9,2 \\
Total & 153 & 100,0 \\
\hline
\end{tabular}

Jenis terapi untuk dermatofitosis dapat diketahui juga berdasarkan penelitian ini yaitu untuk $68.6 \%$ kasus ditangani dengan terapi topikal (Tabel 6). Terapi ini paling sering menggunakan ketokonazole $\mathrm{cr}$. disertai anti histamin oral.

Tabel 6. Distribusi Kasus Dermatofitosis Berdasarkan Terapi Pasien

\begin{tabular}{ccc}
\hline Terapi & JumlahKasus & $\mathbf{( \% )}$ \\
\hline Topikal & 105 & 68,6 \\
Sistemik & 14 & 9,2 \\
Kombinasi & 34 & 22,2 \\
Total & 153 & 100,0 \\
\hline
\end{tabular}

Pemberian anti jamur topikal bertujuan membantu eradikasi dermatofita dari kulit untuk menghindari penyebaran di sekitar daerah yang terkena, juga untuk mengurangi resiko penularan pada orang lain. ${ }^{12}$ Pada kasus yang ditangani dengan terapi kombinasi diberikan obat anti jamur sistemik (griseofulvin, itrakonazole, ketokonazole) yang dikombinasi dengan topikal anti jamur (ketokonazole cr.). Pada kasus seperti tinea kapitis, sejalan dengan penetrasi dermatofita ke dalam folikel rambut, maka untuk infeksi yang mengenai rambut diberikan pengobatan oral (Tabel 6).$^{7}$

\section{BAHASAN}

Berdasarkan penelitian retrospektif 
yang sudah dilakukan di Poliklinik Kulit dan Kelamin serta Instalasi Rekam Medik di RSUP Prof. Dr. R. D. Kandou Manado untuk tahun 2013 didapatkan 153 (3,7\%) kasus dermatofitosis dari total 4099 kasus penyakit kulit dan kelamin di Poliklinik Kulit dan Kelamin. Hasil ini menunjukan peningkatan dari penelitian sebelumnya di RSUP Prof. Dr. R. D. Kandou Manado periode Januari - Desember 2012 dengan persentase kasus dermatofitosis saat itu sebesar $1,6 \%{ }^{11}$ Terjadinya peningkatan sebesar dua kali lipat ini dapat disebabkan beberapa faktor, seperti adanya kesadaran masyarakat untuk memeriksakan diri ke rumah sakit atau bisa juga karena berbagai hambatan yang terjadi di penelitian tahun sebelumnya sehingga data yang didapatkan kurang memadai.

Distribusi kasus dermatofitosis berdasarkan klasifikasi menurut lokasinya didapatkan kasus terbanyak yaitu tinea kruris dengan 54 (35,3\%) kasus (Tabel 2). Hasil penelitian sebelumnya juga menunjukan tinea kruris sebagai kasus dermatofitosis tertinggi sebesar 55,38\%. Hal ini menunjukan bahwa terjadi penurunan dari segi statistik pada tahun 2013 dari tahun sebelumnya. ${ }^{11}$ Tinea kruris merupakan kejadian tertinggi kedua setelah tinea korporis untuk kasus dermatofitosis di seluruh dunia. ${ }^{3}$ Tinea kruris banyak terjadi di daerah beriklim tropis seperti Indonesia. Faktor kejadian tinea kruris juga dipengaruhi kelembaban iklim dan higenitas diri. ${ }^{9}$ Selain itu berdekatan dengan sumber penularan seperti kontak langsung dengan penderita lain, berbagi handuk dan alas tempat tidur dapat diperhitungkan sebagai faktor resiko namun hal ini juga masih perlu diteliti lebih lanjut. Penurunan persentasi kasus tinea kruris dari tahun sebelumnya bisa disebabkan oleh peningkatan higenitas diri oleh masyarakat yang semakin sadar dan mengerti bahwa kesehatan harus diimbangi dengan tingkat kebersihan baik diri sendiri maupun lingkungan. Selain itu pengetahuan dan kepedulian terhadap kesehatan terutama pada kulit sudah semakin meningkat.
Dermatofitosis dilihat dari distribusinya berdasarkan umur, didapatkan golongan umur terbanyak yaitu 45-64 tahun sebesar 32,7\% (Tabel 3). Penelitian oleh Hidayanti et al. $^{13}$ di RS Dr. Soetomo Surabaya menunjukan kasus dermatofitosis sering terjadi pada rentang usia produktif. Hal yang sama pada penelitian oleh Bertus ${ }^{11}$ tahun 2012 di RSUP. Prof. Dr. R. D. Kandou Manado didapatkan hasil terbanyak pada usia 43-64 tahun atau dewasa tua dengan 32 (49.24\%) kasus. Hal ini dapat disebabkan faktor pertahanan tubuh yang menurun seiring dengan pertambahan usia. $^{6}$ Adanya penurunan metabolisme di usia ini dapat mengakibatkan obesitas yang menghasilkan lipatan-lipatan pada beberapa bagian tubuh. Mengingat kelompok ini masih termasuk usia bekerja, jika ditambah dengan faktor aktivitas yang menghasilkan keringat dan tidak diimbangi dengan kebersihan diri maka akan menyebabkan peningkatan resiko terkena dermatofitosis. Saat ini tidak ditemukan bukti statistik berarti namun pada umumnya untuk golongan usia dewasa dan anak-anak terdapat perbedaan infeksi jenis dermatofitosis tertentu. Seperti tinea kapitis yang lebih sering ditemukan pada anak-anak atau tinea kruris yang lebih sering mengenai laki-laki usia dewasa, ${ }^{9}$ namun pada dasarnya dermatofitosis dapat menyerang golongan usia manapun. ${ }^{3}$

Distribusi dermatofitosis berdasarkan jenis kelamin untuk penelitian di RSUP. Prof. Dr. R. D. Kandou Manado tahun 2013 didapatkan kasus pada pasien berjenis kelamin perempuan lebih banyak dibandingkan laki-laki dengan persentasi 60,8\% (Tabel 4). Hasil ini sebanding dengan penelitian tahun 2012 bahwa perempuan juga merupakan kasus terbanyak untuk distribusi dermatofitosis berdasarkan jenis kelamin. Secara global kasus terbanyak untuk dermatofitosis biasanya pada laki-laki dewasa yang 3 kali lebih berisiko terutama pada kasus tinea kruris, ${ }^{3}$ tapi hal tersebut tidak dapat dijadikan gambaran untuk keseluruhan populasi. Hal ini dapat disebabkan tidak seimbangnya komposisi jenis kelamin 
sampel. Jumlah kunjungan pasien perempuan lebih banyak dari laki-laki. Kemungkinan faktor lainnya bahwa perempuan cenderung lebih memperhatikan perubahan penampilan sehingga terdorong untuk memeriksakan diri.

Pada distribusi dermatofitosis berdasarkan pekerjaan didapatkan bahwa ibu rumah tangga merupakan kasus dermatofitosis terbanyak dengan 35 (22,9\%) kasus (Tabel 5). Hal ini sejalan dengan persentase sebelumnya bahwa jenis kelamin perempuan lebih banyak terkena dibandingkan laki-laki. Pekerjaan domestik ibu rumah tangga banyak melibatkan panas dan lembab, dua hal ini merupakan suasana berkembang biak yang baik untuk jamur. ${ }^{7}$ Jika tidak membersihkan diri dengan baik sebelum dan terutama setelah melakukan pekerjaan maka kemungkinan terkena dermatofitosis meningkat. Selain itu pekerjaan ibu rumah tangga merupakan kegiatan rutin atau berulang setiap hari dan menjadi seperti kebiasaan, sehingga jika ada kebiasaan yang tidak higenis yang terus diulang akan memperbesar resiko untuk terkena dermatofitosis. Perbedaan iklim, geografis, lingkungan hidup, serta gaya hidup lebih mungkin menjadi faktor yang berpengaruh terhadap kejadian dermatofitosis. $^{\text {? }}$

Jenis terapi untuk dermatofitosis dapat diketahui juga berdasarkan penelitian ini yaitu untuk $68.6 \%$ kasus ditangani dengan terapi topikal (Tabel 6). Terapi ini paling sering menggunakan ketokonazole cr disertai anti histamin oral. Pemberian anti jamur topikal bertujuan membantu eradikasi dermatofita dari kulit pasien untuk menghindari penyebaran di sekitar daerah yang terkena, juga untuk mengurangi risiko penularan pada orang lain. ${ }^{12}$ Pada kasus yang ditangani dengan terapi kombinasi diberikan obat anti jamur sistemik (griseofulvin, itrakonazole, ketokonazole) yang dikombinasi dengan topikal anti jamur (ketokonazole cr.). Pada kasus seperti tinea kapitis, sejalan dengan penetrasi dermatofita ke dalam folikel rambut, maka untuk infeksi yang mengenai rambut diberikan pengobatan oral. ${ }^{7}$

\section{SIMPULAN}

Berdasarkan hasil penelitian dapat disimpulkan bahwa dari 153 kasus dermatofitosis di Poliklinik Kulit dan Kelamin RSUP. Prof. Dr. R. D. Kandou Manado tahun 2013 tinea kruris sebagai lokasi dermatofitosis tersering dan terapi kombinasi yang paling sering digunakan untuk kasus dermatofitosis.

\section{SARAN}

Masyarakat perlu diberikan edukasi mengenai faktor resiko dan cara penularan dermatofitosis untuk mencegah penyebaran yang lebih luas.

Sebaiknya pendataan dermatofitosis dilakukan dengan lebih lengkap dan terperinci agar memudahkan pengambilan data untuk penelitian selanjutnya.

\section{DAFTAR PUSTAKA}

1. Rihatmadja R. Anatomi dan faal kulit. In: Djuanda A, Hamzah M, Aisah S, editors. Ilmu Penyakit Kulit dan Kelamin (7th ed). Jakarta: Balai Penerbit FKUI, 2015; p. 3-6.

2. Siregar RS. Atlas Berwarna Saripati Penyakit Kulit. Jakarta: EGC, 2003.

3. Verma S, Hefferman MP. Superficial Fungal Infection: Dermatophytosis, Onichomycosis,Tinea Nigra,Piedra. In: Wolff K, Goldsmith L, Katz S, Gilchrest B, Paller A, Leffell O, editors. Fitzpatrick's Dermatology in General Medicine (7th ed). New York: McGraw-Hill, 2008; p. 180721.

4. Koksal F, Er E, Samasti M. Causative agents of superficial mycoses in Istanbul, Turkey: retrospective study. Mycopathologia. 2009;168(3):117-23.

5. Sobera JO, Elewski BE. Infections, infestations and bites: Fungal diseases. In: Bolognia JL, Jorizzo JL, Rapini RP, editors. Dermatology (2 nd ed). New York: Mosby Elsevier, 2008; p. 1135-49.

6. Kurniawati RD. Faktor-faktor yang berhubungan dengan kejadian tinea pedis pada pemulung di TPA Jatibarang Semarang [Tesis]. Semarang: Universitas Diponegoro; 2006. 
7. Budimulya U, Widaty S.Dermatofitosis. In: Djuanda A. Hamzah M, Aisah S, editors. Ilmu penyakit kulit dan kelamin (7th ed). Jakarta: Badan penerbit FKUI, 2015; 109-16.

8. Nadalo, D; Montoya, C; Hunter-Smith, D. What is the best way to treat tinea kruris. The Journal of Family Practice. 2010;55 (3):256-8.

9. Hay RJ, Ashbee HR, Morre M. Mycology. In: Champion RH, Burton JZ, Burns DA, Breatnach SDM, editors. Rook/Wilkinson/Ebling Textbook of Dermatology (8th ed). Oxford: Blackwell Science, 2008; p 1674-707.

10. Adiguna MS. Epidemiologi Dermatomikosis di Indonesia. In: Budimulya U, Kuswadji, Bramono K, Menaldi
SL, Dwihastuti P, Widati S, editors. Dermatomikosis Superfisialis (3rd ed). Jakarta: Balai Penerbit FKUI; 2004; p. 1-6.

11. Bertus NVP. Profil Dermatofitosis di Poliklinik Kulit dan Kelamin RSUP Prof. Dr. R. D. Kandou Manado periode Januari-Desember 2012. Jurnal e-Clinic 2015;3.

12. Gadithya IDG, Darmada IG, Mas ML. Laporan kasus tinea korporis et kruris. eJurnal Medika Udayana. 2014;3(4).

13. Hidayanti AN, Suyoso S, Hinda D, Sandra E. Mikosis Superfisialis di Divisi Mikologi Unit Rawat Jalan Penyakit Kulit dan Kelamin RSUD. Dr. Soetomo Surabaya Tahun 20032005. Berkala Ilmu Kesehatan Kulit dan Kelamin. 2009;21. 